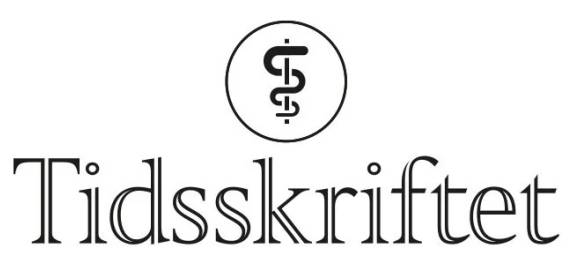

DEN NORSKE LEGEFORENING

\title{
Ingen er fri før alle er fri
}

FRA REDAKTØREN

MARTINE ROSTADMO

martine.rostadmo@tidsskriftet.no

Martine Rostadmo er lege og publiseringsredaktør i Tidsskriftet.

\section{2 er skeivt kulturår. Kan vi lære av fortiden og ta et oppgjør med egne fordommer og kultur?}

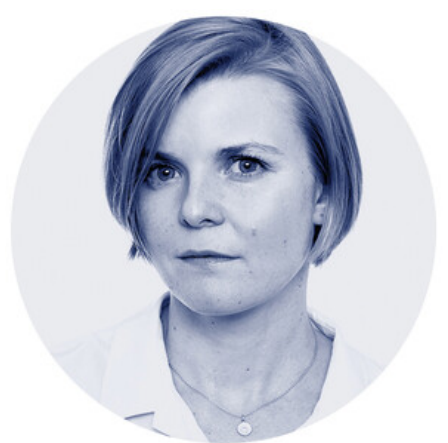

Foto: Sturlason

«Alle tok det pent!» Broren min hadde akkurat kommet ut av skapet. Han var tydelig lettet og glad. Først delte jeg hans glede, så følte jeg meg ille til mote. Som heteroseksuell

ciskvinne har jeg aldri behøvd å ta denne runden, der venner, familie og fremmede skulle komme med tilbakemelding på min legning. Jeg følger normen og slipper således unna. Jeg merker ikke at boksene finnes, at de er trange.

Det er 50 år siden homofili ble avkriminalisert. Det tar åpenbart mer enn 50 år å fjerne all skam, for i alle grupper av skeive i Norge er det en stor andel (37-6o \%) som gjør noe for å skjule sin seksuelle orientering eller kjønnsidentitet minst månedlig (1).

I straffeloven § 213, som ble fjernet i 1972, var seksuell omgang mellom menn sidestilt med det å ha sex med dyr (2). Forløperen fra 1687 var kort og streng: «Omgængelse, som er imod Naturen, straffis med Baal og Brand».

Simonette Vold (ca. 178o - 1873) ble tiltalt for å ha drevet omgjengelse mot naturen med to av tjenestepikene sine, Olava Nielsdatter og Birgitte Marie Burin i 1847, og saken gikk helt til Høyesterett (3). Man antok at kvinner som søkte andre kvinner, hadde unormalt stor klitoris som kunne brukes til penetrering, så Vold ble innkalt til legeundersøkelse. Legen fant hennes anatomi helt normal, hun kunne ikke ha penetrert noen med sitt kjønnsorgan. 
Alle de tre involverte tilsto at de hadde «dasket fladkunt». Dette innebar at Simonette Vold hadde lagt seg oppå de to andre «som Mandfolk paa Fruentimmer». Men var dette «omgjengelse»?

Det måtte distriktslegen avgjøre. Han vurderte at å «daske fladkunt» bare kunne oppvekke kjønnsdriften, ikke tilfredsstille den, og derfor var det ikke omgjengelse. Men: Det verserte rykter om en fløyelsdildo, en løsfyr i datidens språk, en «Indretning som en mandlig Kjønsdeel, der skulde være forfærdiget af fløiel». Både Vold og tjenestepikene benektet at denne løsfyren eksisterte, og selv etter avhør av flere vitner ble det aldri bevist at den fantes. De kunne derfor ikke dømmes. Imidlertid hadde de skapt slik skandale i lokalsamfunnet at de heller ikke kunne gå ustraffet, og for «forargeligt, uteerligt forhold» ble Vold straffet med tukthus i ett år, mens tjenestepikene fikk 15 dagers fengsel på vann og brød.

\section{«Debatten om kjønns- og seksualitetsmangfold preges fremdeles av hva} som er biologi, og dermed hva som er mot naturen»

Fortiden er prolog. Majoriteten hadde, da som nå, definisjonsmakten. Lesbisk kjærlighet ble definert ut fra mannens perspektiv, det måtte være noen form for «mandlig Kjønsdeel» involvert. Og distriktslegen hadde mer makt enn han hadde sexologisk kompetanse - noe helsevesenet stadig mangler (4).

Forbudet mot homofili var begrunnet med at man var redd for at unge gutter skulle påvirkes og dermed utvikle homofili. Nå er enkelte bekymret for at kjønnsdysfori smitter. Debatten om kjønns- og seksualitetsmangfold preges fremdeles av hva som er biologi, og dermed hva som er mot naturen. Men hvordan «naturen» defineres, er avhengig av historisk kontekst (5).

Helsevesenet har ikke møtt transpersoner på en god måte (4). Frem til 2016 var det et krav at transpersoner skulle kastreres for å endre juridisk kjønn (ㅁ) , altså fjerne helt friske kroppsdeler og med dem muligheten til å få barn, for å passe inn i noen andres definisjon av «mann» eller «kvinne». Dette var antakelig et brudd på menneskerettighetene (7,,$\underline{8})$, og $\mathrm{i}$ hvert fall ikke god medisin. En av tre transpersoner i siste levekårsundersøkelse hadde forsøkt å ta sitt eget liv (1). Ingen vet hvor mange vi har mistet. Når noen definerer seg utenfor boksen for mann eller kvinne, gjør det fremdeles så vondt at vi synes det er tryggest å la være å hjelpe. Man får fjernet brystene om man vil definere seg som mann, men ikke om man definerer seg som ikke-binær (9.).

\section{«Boksene i mitt hode blir den andres trange bur»}

Så hva kan vi bruke skeivt kulturår til? Vi kan starte med å lytte mer til dem det gjelder. Vi kan ta ansvar for at vårt legekontor, eller vår sykehusavdeling, skal være et sted som oppleves inkluderende for alle (므). Kanskje kan vi bli bevisst egne fordommer. For kanskje kommuniserer jeg en underbevisst forventning om at det er en mor der hjemme når barnet kommer til helsestasjonen med far? At det er kona mannen med demens roper etter? Hvilke antakelser har jeg om den unge jenta med hijab?

Å komme ut av skapet er ikke noe man gjør en gang for alle, det må gjentas i hver nye relasjon, på jobbintervju, på foreldresamtale, hos legen og på sykehjemmet. Men hva er egentlig skapet? Det er vel summen av samfunnets forventninger. Boksene i mitt hode blir den andres trange bur.

Min bror har samtykket til å bli omtalt i teksten. 


\section{REFERENCES}

1. Anderssen N, Eggebø H, Stubberud E et al. Seksuell orientering, kjønnsmangfold og levekår. Resultater fra spørreundersøkelsen 2020. Bergen: Universitetet i Bergen, 2020.

https://www.bufdir.no/globalassets/global/nbbf/kjonn_identitet/seksuell_orientering_kjonnsmangf old_og_levekar_resultater_fra_sporreundersokelsen_2020.pdf Lest 17.2.2022.

2. Tveter L. Rett og seksuell orientering - et tilbakeblikk.

https://lovdata.no/artikkel/rett_og_seksuell_orientering__et_tilbakeblikk/2408 Lest 17.2.2022.

3. Skjoldhammer TL. Omgjengelse mot naturen, eller kaade og vellystige friktioner? Historien om Simonette Vold og tjenestepikene hennes. Historieblogg 20.12.2018. https://www.historieblogg.no/? $\mathrm{p}=4279$ Lest 17.2.2022.

4. Benestad EEP, Thesen J, Aars H et al. Helsevesenet svikter transpersoner. Tidsskr Nor Legeforen 2017; 137. doi: 10.4045/tidsskr.17.0422. [PubMed][CrossRef]

5. Slagstad K. The Political Nature of Sex - Transgender in the History of Medicine. N Engl J Med 2021; 384: 1070-4. [PubMed][CrossRef]

6. Brean A. Hun, han, hen og alle andre. Tidsskr Nor Legeforen 2015; 135: 1919. [PubMed][CrossRef]

7. Amnesty International. Tvinges til sterilisering. Publisert 25.5.2012. https://amnesty.no/tvinges-tilsterilisering Lest 17.2.2022.

8. Sørlie A. Tvungen identitet - en vurdering av norsk forvaltningspraksis' krav om irreversibel sterilisering ved endring av juridisk kjønn. Tidsskrift for familierett, arverett og barnevernrettslige spørsmål 2014; 12: 272-95. https://www.duo.uio.no/handle/10852/50530 Lest 17.2.2022.

9. Svendsen M. Mina får ikke støtte til å fjerne brystene. NRK 18.1.2O22.

https://www.nrk.no/trondelag/mina-far-ikke-kjonnsbekreftende-behandling-pa-oslouniversitetssykehus-1.15807893 Lest 17.2.2022.

10. Foreningen for kjønns- og seksualitetsmangfold. Rosa kompetanse - Helse og sosial. https://www.foreningenfri.no/rosa-kompetanse/rk-helse-og-sosial/ Lest 17.2.2022.

Publisert: 24. februar 2022. Tidsskr Nor Legeforen. DOI:10.4045/tidsskr.22.0138

(C) Tidsskrift for Den norske legeforening 2023. Lastet ned fra tidsskriftet.no 26. april 2023. 